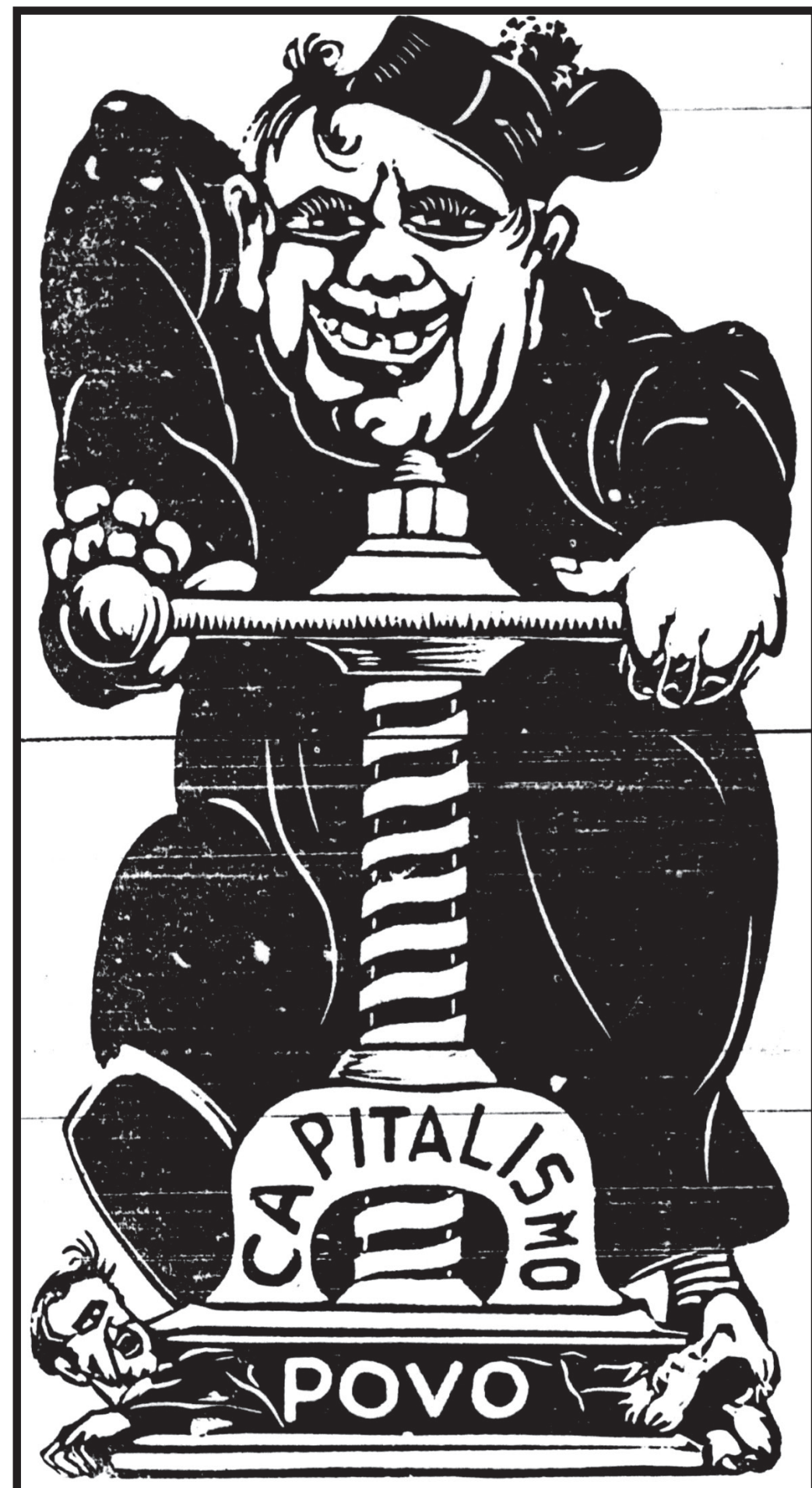

Essa é a situação: O clero ao servico do cupitalisma está sempre com ele na exploração do poro.

Figura 3 - O padre

Fonte: A Plebe, 1 jul. 1947. Arquivo Edgard Leuenroth 


\title{
Bestiário da Autoridade: Representação Iconográfica do Periódico Anarquista A Plebe
}

\author{
Daisy de Camargo
}

Doutora em História pela UNESP/Assis. Atualmente realiza um Pós-Doutorado pela Unifesp. Bolsista FAPESP. Trabalhou como Historiadora no Museu da Imagem e do Som de São Paulo (1990-1996) e no CONDEPHAAT (2000- 2007).E-mail: daisydecamargo@yahoo.com.br..

\section{Resumo}

Este estudo trata do imaginário nas representações iconográficas publicadas no periódico anarquista paulistano A Plebe (1917-1951). Explora o território da resistência na utilização da inter-relação entre o grotesco, o apavorante e até nos vestígios de humor negro para representar os principais alvos alegorizados pelos anarquistas: o burguês, o integralista e o clérigo.

Palavras-chave: Imprensa. Anarquismo. Arte. Iconografia.

\section{Abstract}

This study focuses on the imaginary iconographic representations anarchist periodical published in Sao Paulo, A Plebe (1917-1951). Explores the territory of the resistance in the relationship between the grotesque and the terrifying and even traces of humor in black to represent the main targets allegorized by anarchists: the bourgeois, the integralista and the cleric.

Keywords: Press. Anarchism, Art. Iconography. 
O sono da razão produz monstros. ${ }^{1}$ (Francisco Goya)

\section{O encaminhamento deste estudo} está ligado a uma intenção interpretativa da resistência no imaginário das representações iconográficas (enquanto sistema de alegorias ${ }^{2}$ ) publicadas no periódico anarquista A Plebe (19171951).

Esse jornal foi fundado por Edgard Leuenroth - tipógrafo, jornalista e militante anarquista - que participou ativamente da greve geral de 1917 em São Paulo. Em 8 de julho deste mesmo ano surgiu $A$ Plebe, que viria a ter grande penetração, chegando a ter periodicidade diária em 1919.

Dentro de um conjunto de cerca de 200 imagens sistematizadas $^{3}$, elenquei

1 Referência a uma inscrição da cena 43 de Caprichos de Goya, na qual um pintor adormecido é atacado por corujas e morcegos gigantes. $2 \mathrm{Na}$ origem etimológica da palavra alegoria, allos significa outro e agoreuein quer dizer falar na ágora, usar linguagem pública. Falar em forma de alegoria significa, através de uma linguagem literal e acessível, remeter-se a outro nível de significação, a saber: "dizer uma coisa para significar outra”. (BENJAMIN, 1984. p. 37). A pertinência de tomar a palavra alegoria como elemento chave para o meu trabalho foi que, através destas imagens, destes personagens que encarnam seres e qualidades bizarras e abstratas, querem dizer uma outra coisa. A alegoria é o grande elemento articulador entre representação e imaginário: ela é uma forma de expressão, de representação. A concepção do imaginário como função criadora é construída pela via alegórica, que expressa a vontade de reconstrução do real dentro de um universo paralelo de sinais. A alegoria se expressa através de uma imagem (que é o seu componente espacial) e de um sentido, que se remete a um significado que vai além da representação explícita. Por meio da imaginação alegórica, mostra-se uma coisa (ou ideia) através de outra. A alegoria é uma figura retórica. 3 As autorias das imagens não foram alguns temas, dos quais pretendo explorar nesse artigo os seguintes: o clericalismo, o capitalismo e o integralismo.

O fantasmático e o grotesco ${ }^{4}$ imbricados, como negação e ruptura e como forma de representação do outro, percorre toda a cronologia rastreada no periódico: 1917 a 1951.

O emblema do burguês, porco, gordo, o que acumula e que possui, contraposta à fragilidade do proletariado; a caveira aparece volta e meia na cadeira do capitalista; a máquina de moer homens (morte massificada); as correntes que aprisionam; facas e machados; as bocas ferozes e animalescas dos policiais e integralistas. Todas estas representações ilustram bem esta noção do terror e do grotesco como percurso para a elaboração de um bestiário que denuncia o poder.

A forma de resistência, portanto, é colocada enquanto elemento de representação que mina a autoridade, na medida em que o caótico representado nestas imagens assume uma plenitude de agressividade e crueza como elemento constitutivo da figura.

Disto decorre uma inter-relação entre o grotesco e a materialização do apavorante, pois se trata de um grotesco também sinistro, assumido num contraste entre miséria e riqueza, poder e fragilidade, na representação do burguês, da polícia, dos integralistas, do clero, que são retratados (quase) que como monstros.

identificadas, uma vez que, ainda que pouquíssimas sejam assinadas por codinomes, não havia qualquer fonte informativa sobre os desenhistas e a maioria das gravuras não eram assinadas, talvez até para despistar possíveis perseguições. Sabe-se apenas que a maioria dos desenhistas eram militantes anarquistas. 4 Toma-se aqui o termo grotesco como derivativo de grotta, oculto, cavernoso, sinistro. (BENJAMIN, 1998 ). 
Um dos principais alvos da acidez do discurso anarquista de A Plebe foi o clero, sobretudo pelos padrões e valores que regem o seu sistema educativo, baseado na competitividade e na castração do indivíduo, como coloca Edgar Leuenroth (1963):

Os anarquistas nunca deixaram de denunciar, e com mais veemência o fazem nesta delicada situação de vida no Brasil, o perigo da assoberbante influência clerical que aqui se manifesta em todos os sentidos. A ação do clero romano assume hoje a feição de verdadeiro imperialismo, que estende seus tentáculos por toda a parte.

O ultramontanismo domina soberanamente em todos os setores da vida brasileira. Executando as palavras de ordem ditadas pelos altos poderes do Vaticano, os agentes do governo papalino espalham-se por todos os recantos do país, desde as grandes capitais até pequenos arraiais do sertão brasileiro. Agem no recesso do lar minando as consciências por intermédio do confessionário e das aulas de catecismo ministradas nas sacristias; invadem as repartições públicas, dominam o ensino nas escolas, chegam até às forças armadas, são encontrados nos meios associativos, exploram no comércio e na indústria e dominam na política e nas esferas governamentais. (LEUENROTH, 1963, p. 113)

Lidando com o mesmo discurso, a figura 1 traz um padre de capuz dominando a cena e, no primeiro plano, homens encapuzados e acorrentados carregam cruzes. O agigantamento desproporcional do clérigo em relação aos outros personagens que se arrastam e caem, aprisionados e cegados, rendidos, enfim, dizem muito a respeito desta relação de domínio mental que os anarquistas rejeitam.

Figura 1- Domínio mental

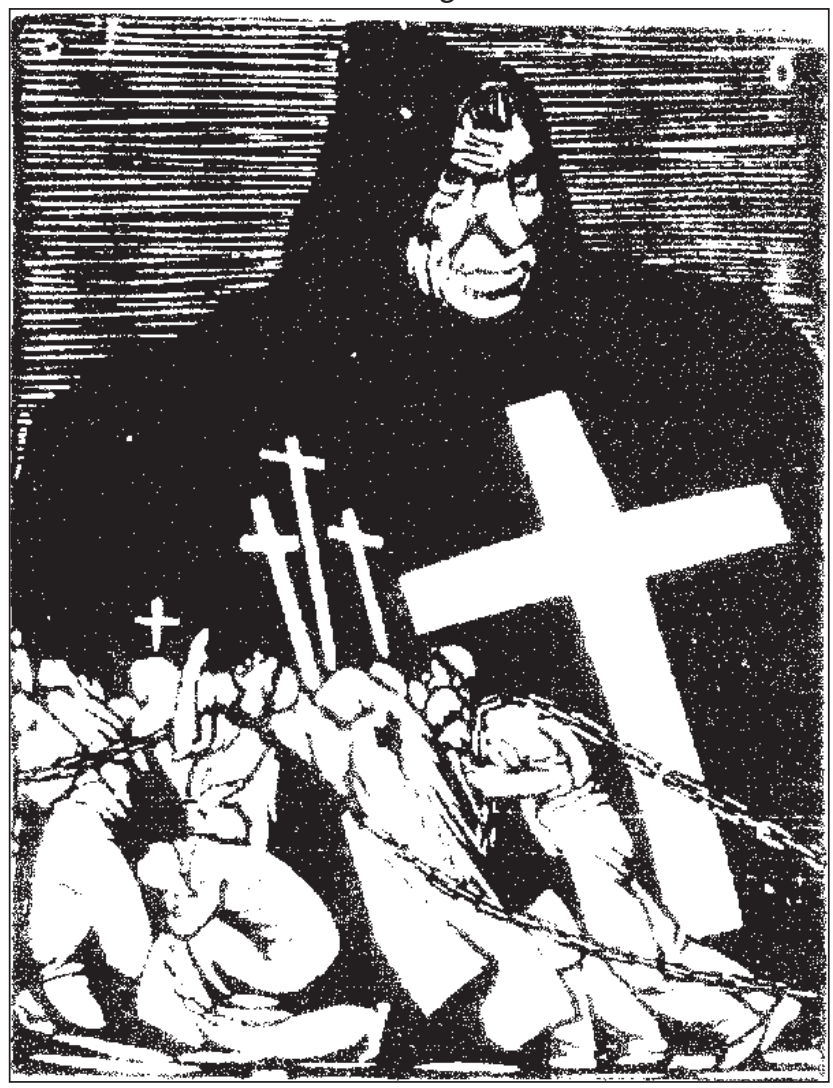

Fonte: A Plebe, 03 set. 1948. Arquivo Edgard Leuenroth 
Ainda nesta mesma narrativa que rejeita a presença do clero na educação, trago aqui um trecho de uma farpa atirada em A Plebe:

Ibitiúva grotesca: De como o 'materialismo' de um bispo faz peccar o seu rebanho [...]

Lamenta-se a carolada não ter ainda um logar onde possa purgar-se de seus peccados [...]. Se não nos condenassem às massadas... celestiaes, nós lhe indicaríamos um logar muito próprio para isso [...]. (A Plebe, 30 jun. 1917, p. 4)

Para os anarquistas, os padrões de valores que regem o comportamento das pessoas passam necessariamente por todo o sistema educativo. Numa sociedade competitiva, na qual os valores são transmitidos desde a infância, através de prêmios e castigos, tudo acaba por contribuir para a alienação do indivíduo, que sofre a influência dos meios de comunicação de massa a serviço de estamentos privilegiados e do Estado.

Partindo do pressuposto de que a liberdade da criança e do adolescente não pode ser lesada, o anarquista diferencia a instrução da educação, onde as crianças possam se desenvolver assumindo sua autonomia e seu espírito crítico. (CUBERO, 1995). Contraposto a isto, está o ensino clerical, que, segundo os anarquistas, busca uma dominação mental sobre o indivíduo, inculcando-lhe não somente valores, mas crenças.

Também no alvo deste discurso da resistência, estão os burgueses. Numa figura (2) publicada em A Plebe, pende do lado esquerdo de uma balança um porco gordo, de paletó e cartola, sorrindo, com \$ na barriga; já do lado direito, vários homens - a única vestimenta identificável é um macacão de operário - pendurados por cordas no pescoço, cabeças abaixadas e enforcados (mortos?).
Figura 2 - Burgues

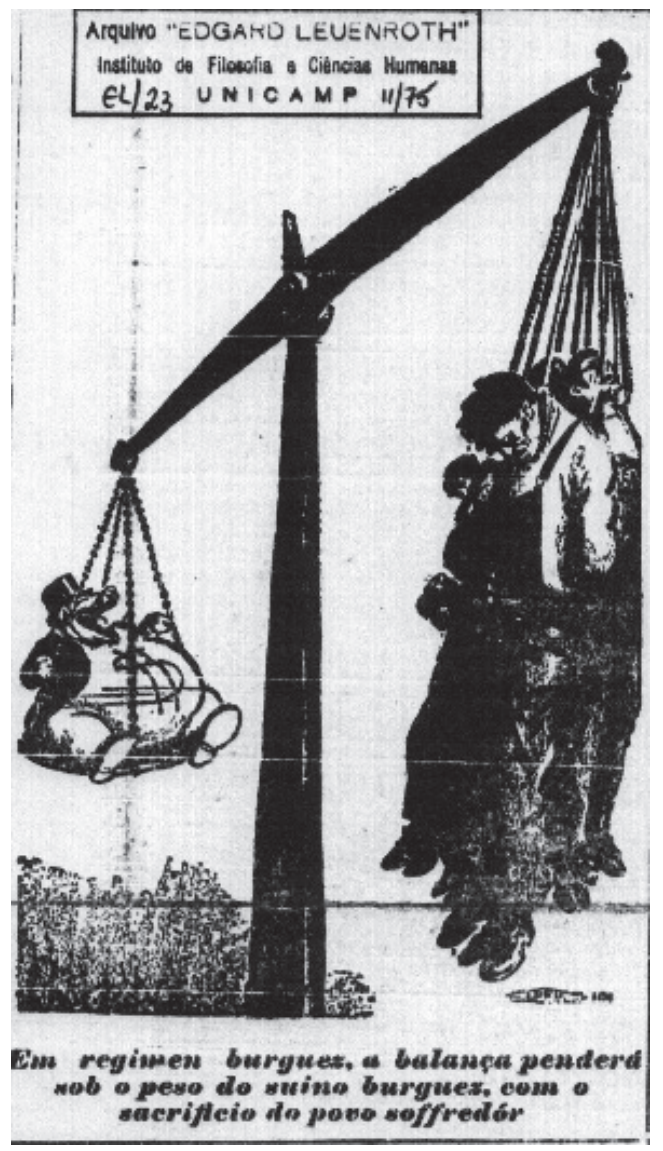

Fonte: A Plebe, 19 jan. 1924. Arquivo Edgard Leuenroth

A legenda acusa: "Em regime burguês, a balança penderá sob o peso do suíno burguês, com o sacrifício do povo sofredor."

No mesmo tom de blasfêmia do discurso figurativo, A Plebe de 1 de setembro de 1917 publica na primeira página um artigo chamado "Desmascarando tartufos", que fala sobre o desrespeito das autoridades ao direito de associação por parte dos operários: "Os bandidos do capital, os pulhas da governança", "malandros", "patifes", "modernos e civilizados bandidos".

Apresentam-se em várias passagens elementos de crítica visual que colocam os capitalistas e os integrantes do clero em 
situações semelhantes. A obesidade presente nos porcos/burgueses também é recorrente nos clérigos representados como elemento de imbecilidade.

Nas figuras 3 e 4, vemos o padre e o burguês, duas imagens ligadas ao capitalismo, à obesidade (acumulação) e à morte: referência dela na caveira acima do $\$$ do trono do burguês e aos homens mortos esmagados pelo peso do padre.

Figura 3 - O padre

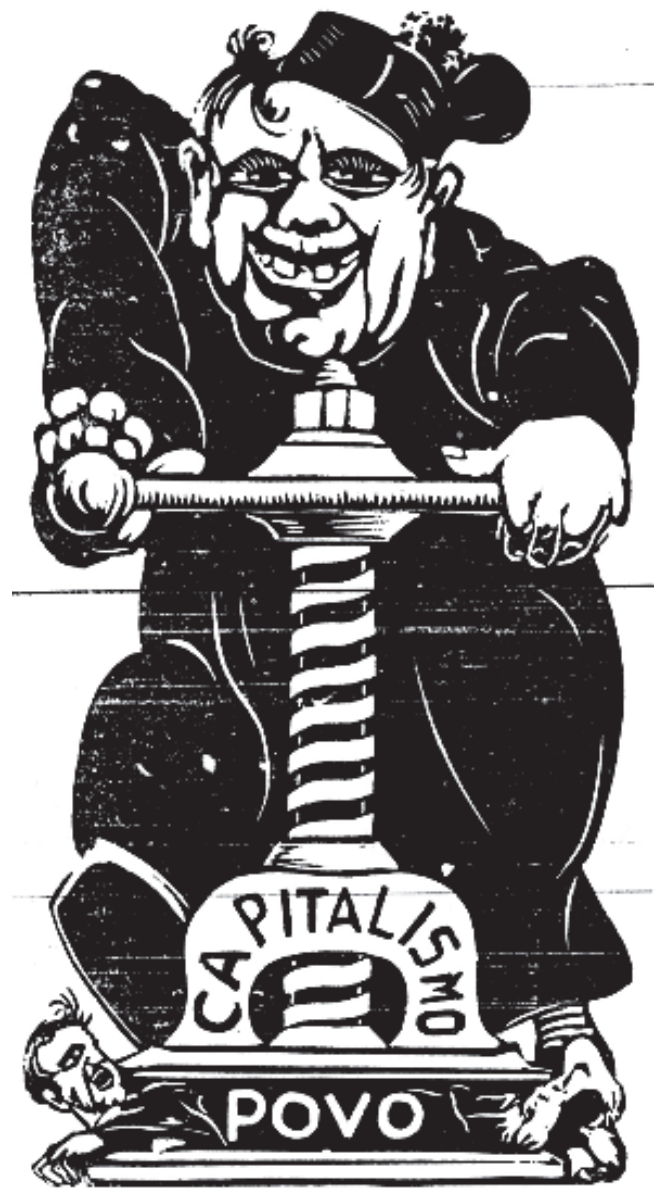

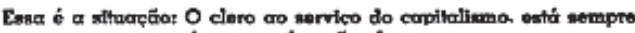
com ole na exploraçto do pora.

Fonte: A Plebe, 1 jul. 1947. Arquivo Edgard Leuenroth
Figura 4 - Capitalismo

O imperador supremo dos homens e das coisas

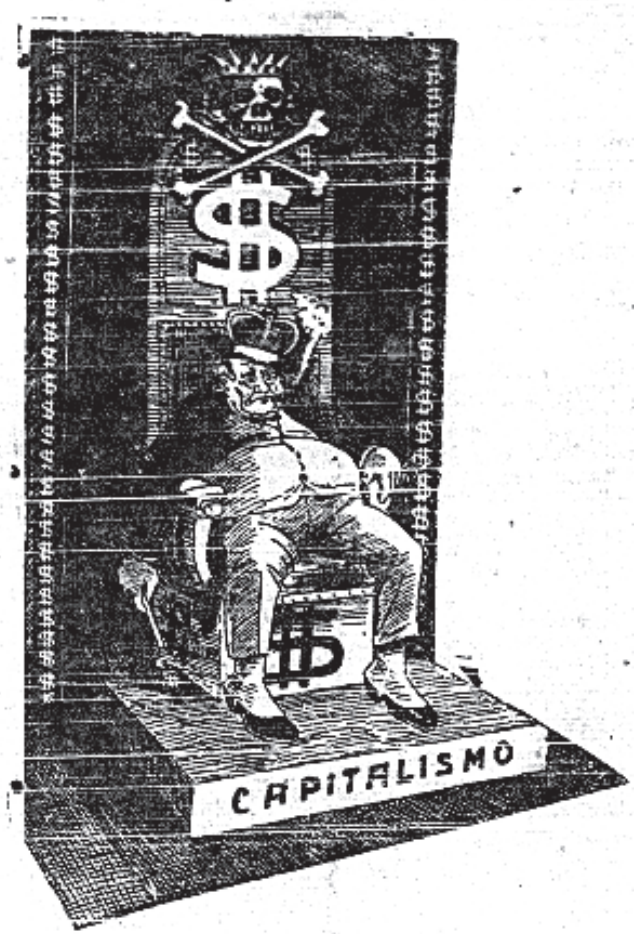

Fonte: A Plebe, 11 jun. 1927. Arquivo Edgard Leuenroth

Para os anarquistas, o clero, os militares e os capitalistas formam os grandes pilares de um regime social cruel que aprisiona o homem, como se fossem três entidades distintas em um só corpo. Coloca-se, portanto, um novo elemento inimigo: o militarismo, e, sobretudo, a ascensão do discurso belicista do fascismo, que viria a culminar na Segunda Guerra Mundial.

A crise do pós-guerra estimulou o crescimento de partidos conservadores radicais, que propagandeavam a idéia de um poder forte, que se sobrepusesse aos interesses individuais.

As greves, para os fascistas, eram atitudes, neste sentido, interpretadas como individualistas ou antissociais. Estes grupos postulavam como valor máximo a coletividade e a nação em oposição ao particular e ao 
individual. Para conter este mal denominado de individualismo, os radicais propunham a necessidade de um governo endurecido, que estivesse presente em todos os momentos e espaços das vidas das pessoas. ${ }^{5}$

No esteio destes movimentos conservadores, formou-se no Brasil a Ação Integralista Brasileira (AIB), grupo político inspirado no fascismo europeu, liderado por Plínio Salgado, que defendia o fortalecimento do Estado e o autoritarismo, como é evidenciado neste manifesto:

A Nação Brasileira deve ser organizada, una, indivisível, forte, poderosa, rica, próspera e feliz. Para isso precisamos que todos os brasileiros estejam unidos. Mas o Brasil não pode realizar a união íntima e perfeita de seus filhos, enquanto existirem Estados dentro do Estado; partidos políticos fracionando a Nação; classes lutando contra classes; indivíduos isolados, exercendo pessoal ação nas decisões do governo; enfim todo e qualquer processo de divisão de povo brasileiro. Por isso, a Nação precisa organizar-se em classes profissionais [...]. Precisamos de autoridade capaz de tomar iniciativas em benefício de todos e de cada um; capaz de evitar que os ricos e os poderosos, os estrangeiros, os grupos políticos exerçam sua influência nas decisões do governo, prejudicando os interesses fundamentais da Nação. Precisamos da hierarquia, de disciplina, sem o que só haverá desordem $[\ldots]^{6}$

5 Benito Mussolini, líder do fascismo italiano, assim pensava sobre o indivíduo: "Antiindividualista: a concepção fascista é feita para o Estado; é-o também para o individuo enquanto faz corpo com o Estado [...] E isso porque, para o fascista, tudo está no Estado, e nada de humano nem de espiritual existe fora do Estado. Neste sentido, o fascismo é totalitário, e o Estado fascista, síntese e unidade de todo valor, interpreta e dá poder à vida inteira do povo. Nem, de agrupamento - partidos políticos, associações, sindicatos-, nem indivíduos fora do Estado." Benito Mussolini apud (FREITAS, 1975, p. 286). 6 Manifesto de Outubro da Ação Integralista Brasileira em 1932. Ação Integralista Brasileira, em 1932. (CARONE, 1978, p. 309-310).
Os integralistas defendiam a ordem, a disciplina e a militarização da sociedade. Chocando-se com estes movimentos de direita, os primeiros anos da década de 1930 são permeados por muitas manifestações operárias, como relata Everardo Dias, militante anarquista:

O governo não se julgava seguro e a agitação social tinha para ele um caráter que se podia transformar em levante armado [...]. Um simples trapo vermelho pendendo de um fio telefônico, na rua, movimentava a polícia e patrulhas do Corpo de bombeiros [...] (DIAS, 1977, p. 177-179).

Um abismo ainda mais estrutural se faria presente entre a noção de Estado totalitário, que pretende a dominação total - centralizando tudo nas mãos do chefe de Estado -, extirpando qualquer oposição e impedindo a existência de instituições que garantam a liberdade individual, e a proposta anarquista.

Este fosso foi representado na violência da ilustração da juventude integralista, com o revólver e em gestuais de sugestão, como é o caso da ênfase no grotesco das feições e das botas, na vestimenta militar e as bocas ferozes e animalescas (ver figura 5). 
Figura 5 - Violência da juventude integralista

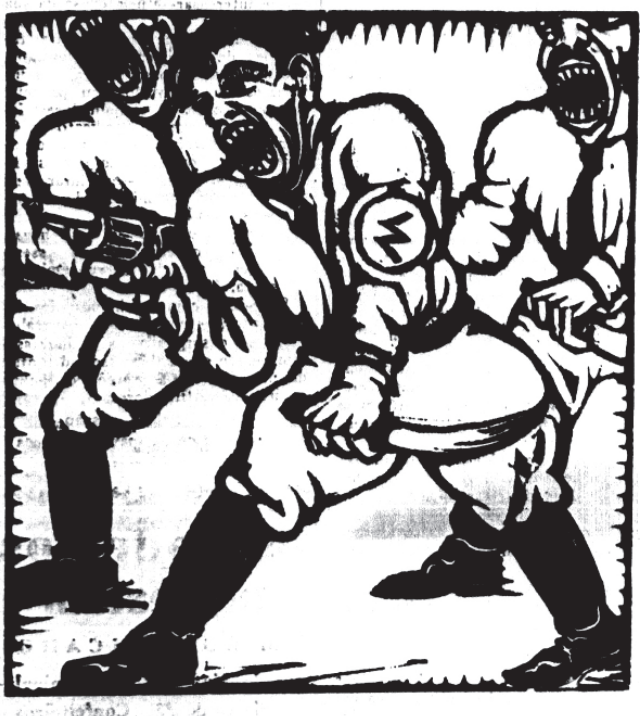

A JUVENTUDE INTEGRALISTA SE DIVERTE... FAZENDO ENSAIOS PARA MASSACRAR OS TRABALHADORES

Fonte: A Plebe, 27 out. 1934. Arquivo Edgard Leuenroth

Representando também este abismo, coloca-se a imagem de um cão (fascismo) com as bocas abertas e dentes afiados, que repousa por entre restos de ossos humanos (ver figura 6). A legenda também acentua: "Aquele que mata a liberdade e devora o corpo dos que a defendem".

Figura 6- Imagem de um cão (fascismo)

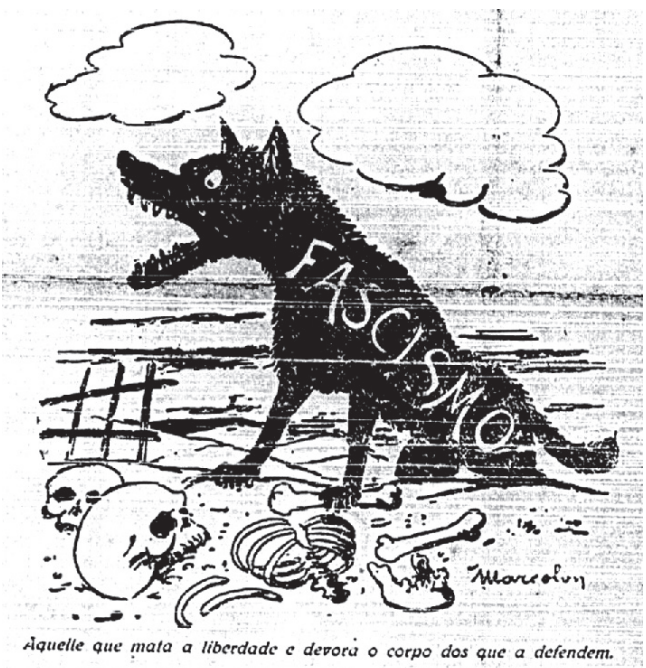

Fonte: A Plebe, 3 dez. 1932. Arquivo Edgard Leuenroth
Também no discurso verbal, o contraponto se coloca. A Plebe publicou na sua primeira página de 3 de dezembro de 1932:

Como pensam os fascistas

A sua sêde de domínio

Lisboa - Na conferência que fez nesta capital, Marinetti, o criador do futurismo, teve esta frase: 'Ser italiano equivale a dominar todas as raças'.

De vez em quando a boca foge-lhes para a verdade. Sim, o que moveu e move a cambada fascista para o assalto ao poder e a sua conservação indefinida é o desejo de mando único, pessoal, exclusivo, é a sede devoradora de domínio indiscutido e indisputado, o monopólio do poder agora na Itália e mais tarde em todo o mundo.

[...]

Essa gente devia ser recebida a batata, a nabos, a ovos podres, a assobios, como aqui fizeram ao Marinetti quando realizou a sua conferência futurista em S. Paulo. (A Plebe, 3 dez. 1932)

Ainda em A Plebe de 7 de outubro de 1933, um artigo não assinado discorre acerca do uso da força e da violência como solução conservadora para os problemas sociais:

\section{O INTEGRALISMO}

É assim que a burguesia resolve os problemas sociais!

Como é preciso fazer gastos para locomover essa gente, que assume proporções fantásticas em quasi todos os países do mundo, aumentam os compromissos do Estado, que terá de recorrer, fatalmente, ao processo de extorsão por meio de impostos sobre o povo, que por sua vez, não podendo fazer frente aos gastos de subsistência, se revolta e protesta, entrando em luta com o capitalismo.

Ha gréves, e consequentemente novos desempregados; mais 'sem trabalho' que vão engrossar as fileiras do exercito da fome...

Conseqüência: como a solução não é possível dessa forma, os governos recorrem à violência; suprimem o direito de reunião, a liberdade individual, entopem os presídios, fuzilam e deportam.

É assim que se institui o fascismo na Itália, o nazismo na Alemanha, e que o sr. Plinio 
Salgado procura instituir o 'integralismo' no Brasil. (A Plebe, 7 out. 1933.

Alegorias sobre este uso da força permeiam no mais das vezes o discurso figurativo, como é o caso da figura 7, publicada em A Plebe em 1934, onde um monstro, com cabeça de homem, cujos traços são grandes e disformes (será Mussolini?), e corpo como o de uma cobra. A cauda está enroscada num ícone da suástica. A mão segura um punhal (honra), sujo de sangue. Esta imagem de grafismo puro, meio cubista, traz uma legenda catalisadora: "FASCISMO: O monstro que pretende devorar a espécie humana".

Figura 7- Monstro- FASCISMO

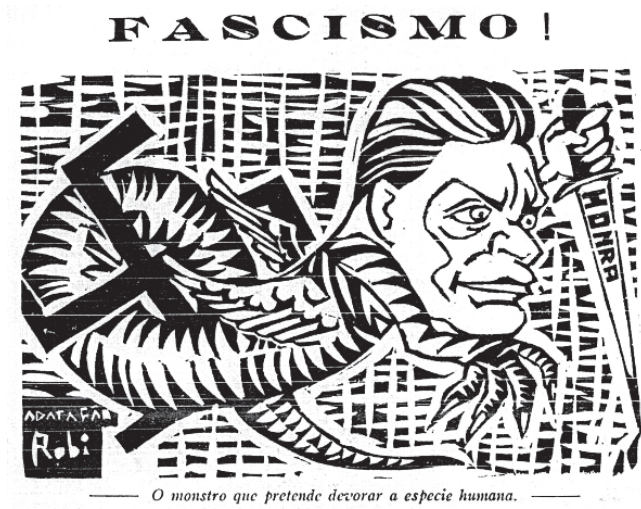

Fonte: A Plebe, 1 set. 1934. Arquivo Edgard Leuenroth

Outra alegoria que pode ser citada é a da figura 8, em que duas cobras se entrelaçam formando a suástica. Suas bocas estão abertas e suas línguas são enormes, parecendo querer dar um bote uma na outra. A legenda diz: "Nazismo! A serpente que devora o povo alemão".
Figura 8 - Nazismo! A serpente que devora o povo alemão

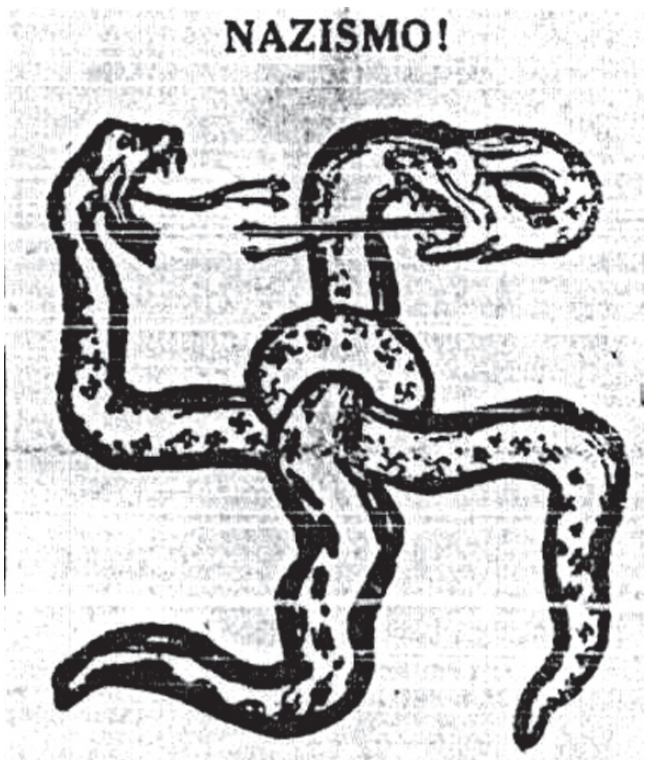

\section{A serpente que devora o povo alemão}

Fonte: A Plebe, 30 set. 1933. Arquivo Edgard Leuenroth

Aglutinando todas estas alegorias numa situação mais localizada, a figura 9 acompanha um texto sobre abusos policiais em relação aos presos políticos. Na imagem, dois policiais (com o símbolo do integralismo nos braços) surram um homem, pendurado numa corda pelas mãos, as costas desnudas, feridas, e a cabeça baixa. Outro jaz no chão sem qualquer sinal de vida. 
Figura 9 - Abusos policiais

\section{Nas pris̄os Infectas da Ruą dos Gusmões apodrecem operarios pelo crine te quererem a emancipação dos trabailhadores}

\section{0 proletarfado se agiı́a com Indigneção confra as violenclas pollcials}

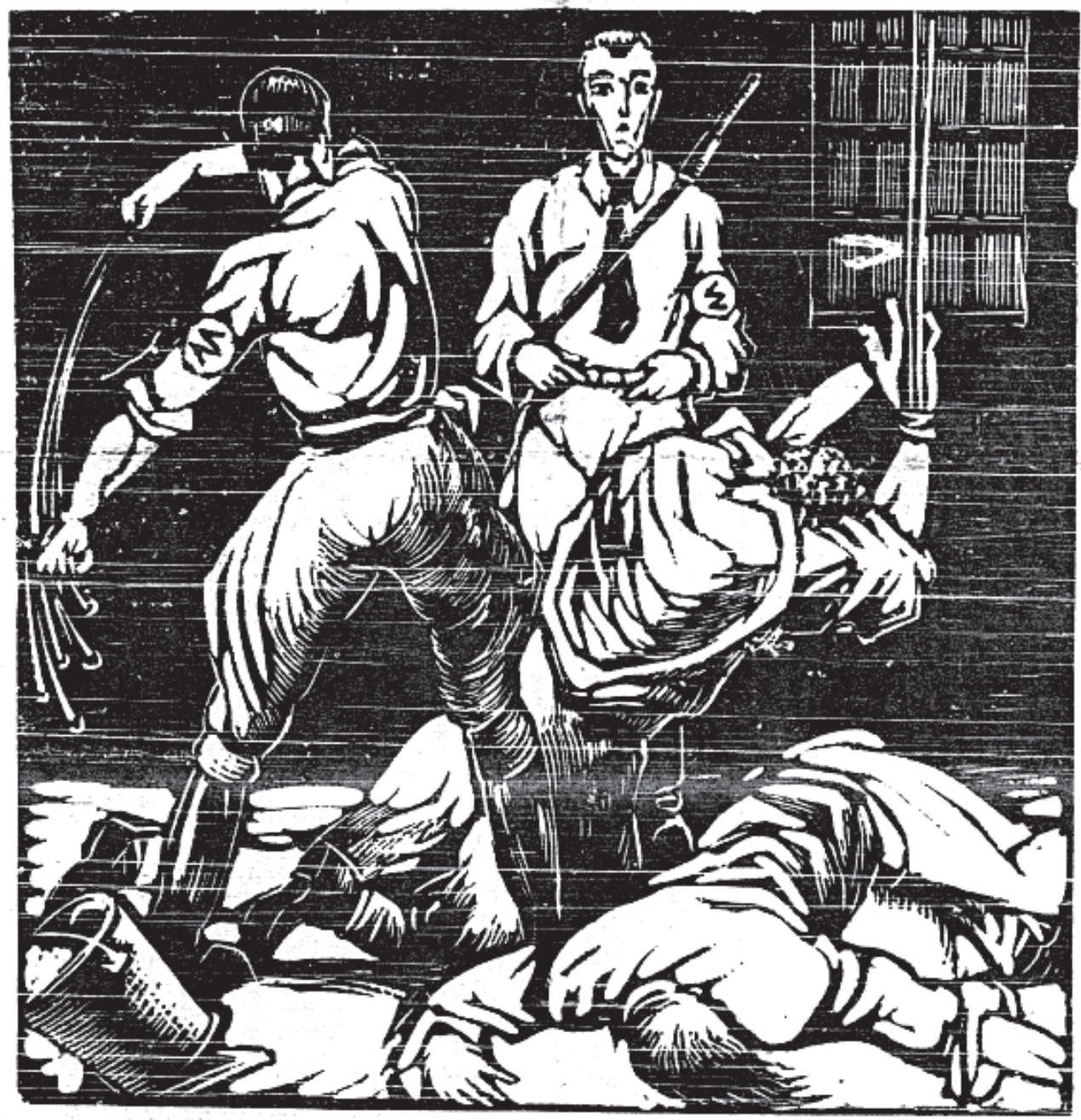

0 regime semi-fascista em que vivemos prende, deporta e sonega á justiça os presos sociais.

$\bar{U}$ regime "integralisia" aspira reublrar sasas violerscias, metendo forturando innuisitorialmente os seus adversarios.

Fonte: A Plebe, 10 nov. 1934. Arquivo Edgard Leuenroth

Na legenda: "O regime semi-fascista em que vivemos prende, deporta, sonega à justiça os presos sociais. O regime integralista aspira redobrar essas violências, matando e torturando inquisitoriamente seus adversários."

Sintetizando todo o seu grupo de adversários, uma última imagem (ver figura 10) traz, do lado esquerdo, padres, integralistas, nazistas, fascistas e um cão 
(reação). Do lado direito, uma multidão camponesa, armada de foices, pás e outros instrumentos de trabalho, aponta o confronto entre os dois grupos debaixo de um céu noturno.

Figura 10 - Multidão camponesa

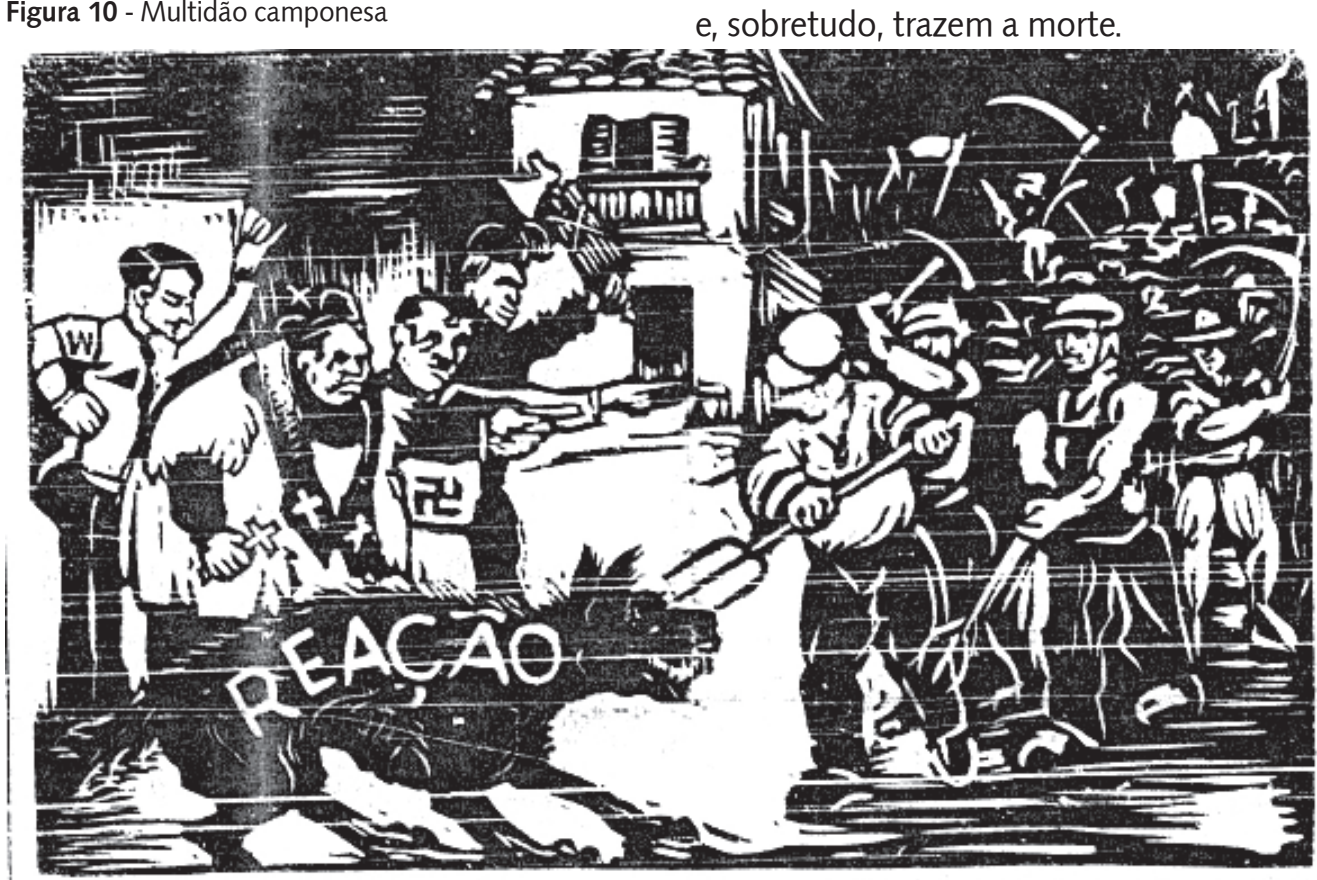

SO UMA ATITUDE DECISIVA DO PROLETARIADO PODERA MMPEDIR O AVANÇO VIOLENTO DA REAÇAO, QUE, AÇULADA PELOS TIRANOS DO FASCISMO E DA BURGUESIA. PRETENDE AYASSALAR O MUNDO.

Fonte: A Plebe, 29 set. 1934. Arquivo Edgard Leuenroth

Este cão, que parece estar à frente de tudo que estes personagens repudiam, tem familiaridade com as forças invisíveis da morte, com os infernos, com o mundo subterrâneo.

Também relacionado a este submundo está o porco/capitalista, que sobrepõe uma representação da comilança e da voracidade. Esta alegoria, já é sabido, devora tudo o que se lhe apresenta. Ele traz uma conotação das chamadas tendências obscuras, nas formas da ignorância, da gula, da luxúria e do egoísmo. Já dizia Heráclito: o porco tira o seu prazer da lama e do esterco. Carrega, portanto, a perversidade, a sujeira e a maldade.

Outra alegoria obscura freqüentemente identificada é a da serpente, uma criatura repugnante e condenada a arrastar-se. Seus poderes são fruto de um roubo, são ilegítimos e malditos, só podem gerar vícios e, sobretudo, trazem a morte. 
outros animais e bestas, tamanha a sua impostura.

Nesse repertório específico aqui recolhido a ameaça tem cara e nome, desenhada num bestiário formado por burgueses, clérigos e integralistas, configurando uma fisiognomia grotesca das autoridades que sustentam o regime capitalista.

E o rabisco destas caricaturas mórbidas está ligado a um humor negro, no que diz respeito a uma racionalidade do abominável. Existe uma racionalidade que gera monstros. E se o grotesco guarda um elemento fantástico, espectral, oculto e enigmático, ligado ao caráter subterrâneo de sua origem - entre ruínas e catacumbas -, este mesmo caráter enigmático tem muito a ver com a representação alegórica, posto que a alegoria fragmenta as coisas (pedaços de seres, animais e objetos) para representá-las em emblemas.

Só a razão poderá vencer estas figuras desprezíveis, estes seres ridículos que tramam contra ela. Fantasias alegóricas especuladas em imagens, essa tendência alegorizante é uma tentativa de controlar o medo destes monstros representados, e assim humilhá-los e fragilizá-los.

\section{Fontes documentais}

Periódico: A Plebe, (1917-1951), Arquivo Edgard Leuenroth.

\section{Referências}

BENJAMIN, Walter. Origem do drama barroco alemão. São Paulo: Brasiliense, 1984.

BENJAMIN, Walter. Origem do drama barroco alemão. São Paulo: Brasiliense, 1998.
CARONE, Edgar. A Segunda República. São Paulo: Difel, 1978.

CUBERO, Jaime. O anarquismo: uma visão da educação da criança na família. In: JORNADA INTERNACIONAL SOBRE INFÂNCIA E VIOLÊNCIA DOMÉSTICA, 1., 1995, São Paulo. Palestra proferida na sessão especial. Mimeo.

DIAS, Everardo. História das lutas sociais no Brasil. São Paulo: Alfa Ômega, 1977.

FREITAS, Gustavo. 900 textos e documentos de história. Lisboa: Plátano, 1975.

LEUENROTH, Edgard. Anarquismo. Roteiro de libertação social. Rio de Janeiro: Mundo Livre, 1963. 